PNL-6742

UC-313

$9 B$

\title{
Test of Dip Cup Instrumentation
}

\author{
B. B. Brenden
}

November 1988

Prepared for the U.S. Department of Energy under Contract DE-ACO6-76RLO 1830

Pacific Northwest Laboratory Operated for the U.S. Department of Energy by Battelle Memorial Institute 


\title{
DISCLAIMER
}

This report was prepared as an account of work sponsored by an agency of the United States Government. Neither the United States Government nor any agency thereof, nor Battelle Memorial Institute, nor any or their employees, makes any warranty, expressed or implied, or assumes any legal liability or responsibility for the accuracy, completeness, or usefulness of any information, apparatus, product, or process disclosed, or represents that its use would not infringe privately owned rights. Reference herein to any specific commercial product, process, or service by trade name, trademark, manufacturer, or otherwise does not necessarily constjtute or imply its endorsement, recommendation, or favoring by the United States Government or any agency thereof, or Battelle Memorial Institute. The views and opinions of authors expressed herein do not necessarily state or reflect those of the United States Covernment or any agency thereof.

\author{
PACIFIC NORTHWEST LABORATORY \\ operated by \\ BATTELLE MEMORIAL INSTITUTE \\ for the \\ UNITED STATES DEPARTMENT OF ENERGY \\ under Contract DE-ACO6-76RLO 1830
}

\begin{tabular}{|c|c|}
\hline \multicolumn{2}{|c|}{ Printed in the United States of America } \\
\hline & \\
\hline \multicolumn{2}{|c|}{ National Technical Information Service } \\
\hline \multicolumn{2}{|c|}{ United States Department of Commerce } \\
\hline \multicolumn{2}{|c|}{5285 Port Royal Road } \\
\hline \multicolumn{2}{|c|}{ Springfield, Virginia 22161} \\
\hline \multirow{2}{*}{\multicolumn{2}{|c|}{$\begin{array}{l}\text { NTIS Price Codes } \\
\text { Micrutiche A01 }\end{array}$}} \\
\hline & \\
\hline \multicolumn{2}{|c|}{ Printed Copy } \\
\hline & Price \\
\hline Pages & Codes \\
\hline $001-025$ & $\mathrm{~A} 02$ \\
\hline $026-0.50$ & A03 \\
\hline $057-075$ & $\mathrm{~A} 04$ \\
\hline 076.100 & A05 \\
\hline $101-\uparrow 25$ & $A 06$ \\
\hline $126-150$ & A07 \\
\hline $151-175$ & $A 0 B$ \\
\hline $176-200$ & $\mathrm{~A} 09$ \\
\hline $201-225$ & A10 \\
\hline $226-250$ & A11 \\
\hline $251-275$ & A12 \\
\hline $276-300$ & A13 \\
\hline
\end{tabular}


TEST OF DIP CUP INSTRUMENTATION

B. B. Brenden

November 1988

Prepared for the U.S. Department of Energy under Contract DE-ACO6-76RLO 1830

Pacific Northwest Laboratory

Richland, Washington 99352 

Instrumentation has been developed which will measure the alumina content of cryolite baths based upon the detection of a thermal arrest in the cooling curve when a small sample is pulled from the bath using a graphite cup. Detection of the temperature at which thermal arrest occurs is automatic, and an alumina content is automatically calculated and displayed. Recent measurements at a production plant indicate a standard error of $0.38 \%$ or less in the determination of alumina content based upon a set of 9 measurements. The time required for a single measurement is less than 5 minutes. No further development of the technique or instrumentation is planned at the present time.

TABLE 1. Summary of Measurement Results

\section{Bath A Bath B}

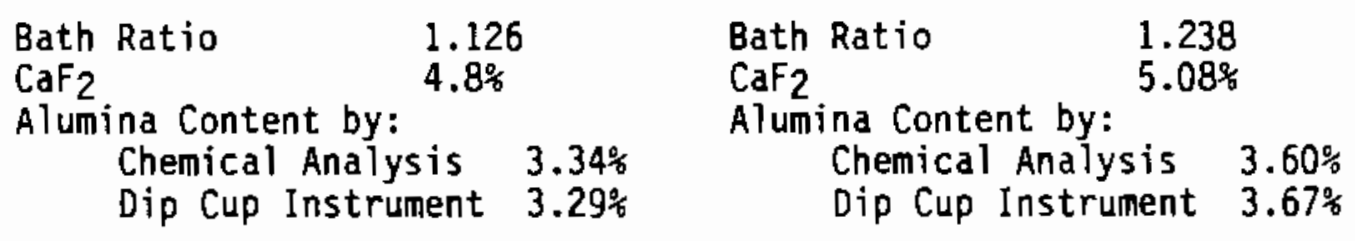





\section{CONTENTS}

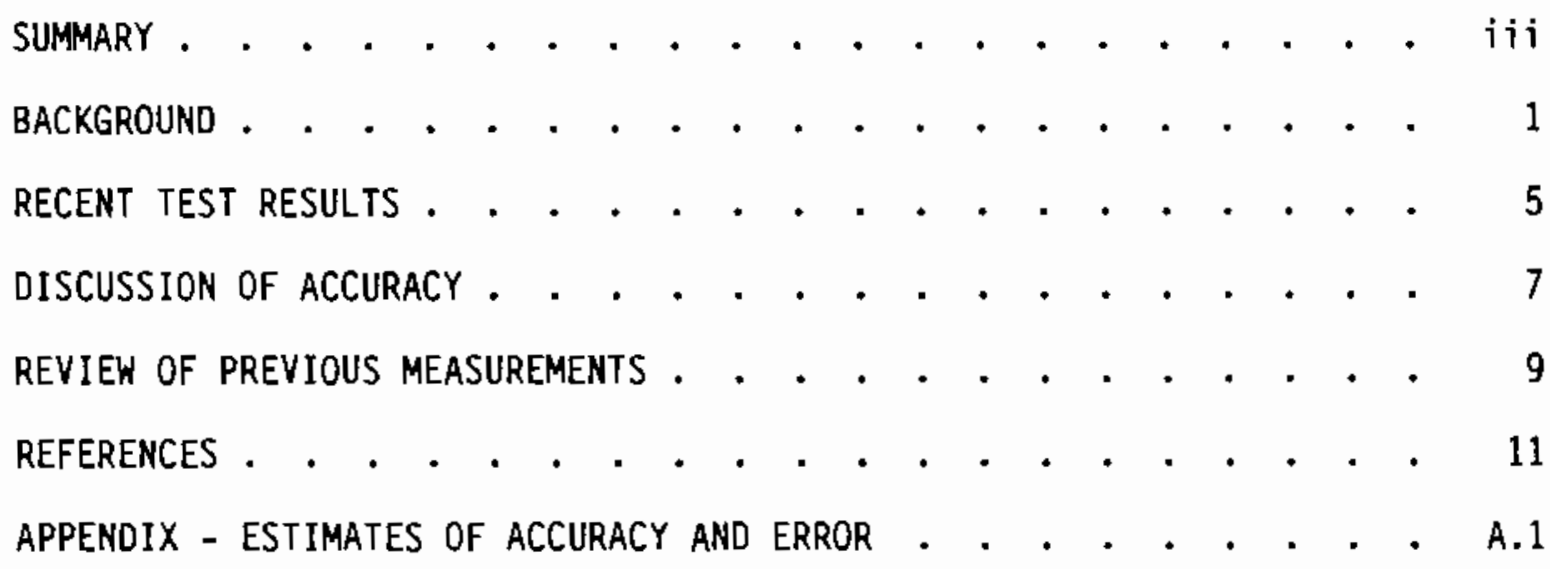




\section{FIGURES}

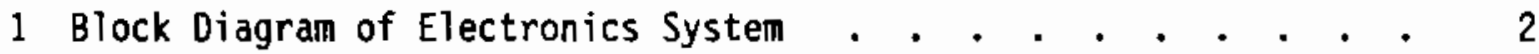

2 Dip Cup Immersed in Cryolite Bath . . . . . . . . . . . 3

\section{TABLES}

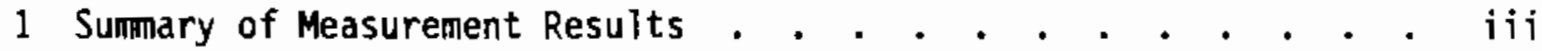

2 Data Taken When Using Automated Dip Cup Instrumentation with High Alumina Content Cryolite Bath . . . . . . . . . . . . 4

3 Summary of Measurement Results . • . . • . . . . . . . . 6

4 Sumary September 22, 1987, Measurements . . . . . . . . . 9 


\section{-}




\section{TEST OF DIP CUP INSTRUMENTATION}

\section{BACKGROUND}

During the course of work to develop instrumentation to measure the alumina content of cryolite baths, a method has evolved based upon the measurement of the temperature at which a thermal arrest occurs during the cooling of a small sample dipped from the bath using a graphite cup having a volume of about three cubic centimeters. Instrumentation has been developed to facilitate the use of this method. The instrumentation is very compact and portable. It consists of a lightweight handling arm which is used to place the dip cup in the bath and an electronics package housed in a small suitcase measuring $21^{\prime \prime} \times 15^{\prime \prime} \times 7 "$. The electronics package, weighing less than 10 pounds, is battery operated and consists of standard commercial equipment including an HP-3421 Data Acquisition System and an HP-71B handheld computer. Figure 1 provides a block diagram of the electronics package. Figure 2 is a schematic drawing showing the dip cup immersed in the cryolite bath.

Tests at the Pacific Northwest Laboratory (PNL) using baths of various bath ratios but containing no spar ( $\mathrm{CaF} 2$ ) gave the results shown in Table 2 . In Table 2 a quality factor is listed which is calculated and displayed by the computer. This is a measure of how well the transition temperature is detected. Note that two of measurements at $6 \%$ alumina had very low quality factors. The data related to the low-quality factors was excluded from the calculation of Mean Values and Standard Deviations. The data indicates excellent repeatability of the transition temperature and its measurement. This translates to excellent repeatability for determination of weight percent alumina. At the time that these measurements were made, the emphasis was upon high alumina content; but it is expected that similar results would be obtained with baths containing less than $6 \%$ alumina.

The instrumentation was introduced to the production environment at the Kaiser Aluminum plant at Mead, Washington, on September 22, 1987. Based upon that experience, further improvements were made to prevent melt off of the dip 


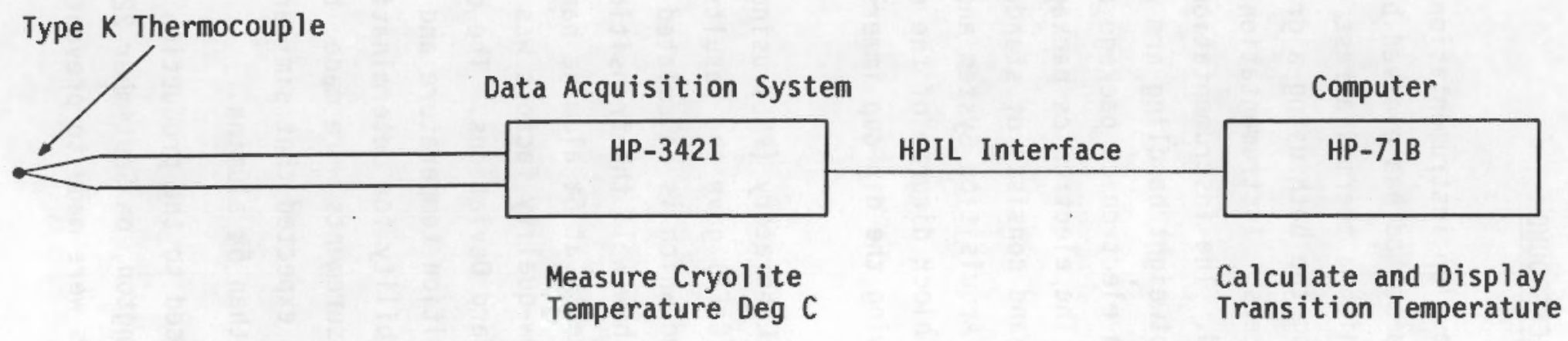

FIGURE 1. Block Diagram of Electronics System 


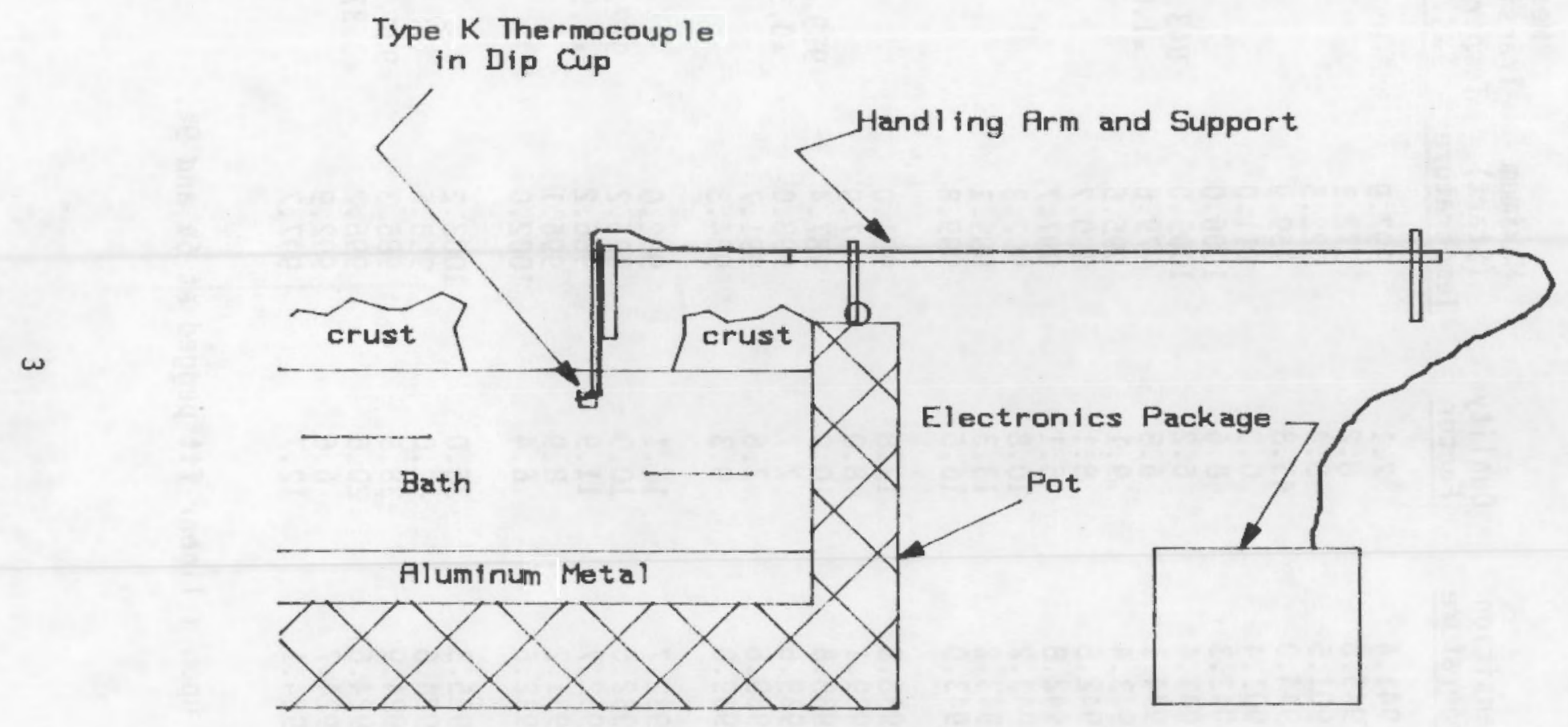

FIGURE 2. Dip Cup Immersed in Cryolite Bath 
cup support, heat damage to the thermocouple connection sockets, and to take into consideration the spar content.

TABLE 2. Oata Taken When Using Automated Dip Cup Instrumentation with High Alumina Content Cryolite Bath

\begin{tabular}{|c|c|c|c|c|c|}
\hline $\begin{array}{l}\text { Wt. } \% \\
\text { Alumina } \\
\end{array}$ & $\begin{array}{l}\text { Transition } \\
\text { Temperature }\end{array}$ & $\begin{array}{l}\text { Quality } \\
\text { Factor }\end{array}$ & $\begin{array}{c}\text { Maximum } \\
\text { (Start) } \\
\text { Temperature } \\
\end{array}$ & $\begin{array}{c}\text { Mean } \\
\text { Transition } \\
\text { Temperature } \\
\pm \text { S.O. }\end{array}$ & $\begin{array}{l}\text { Mean* } \\
\text { Wt.\% } \\
\text { Alumina } \\
\pm S . D \text {. }\end{array}$ \\
\hline $\begin{array}{l}6 \\
6 \\
6 \\
6 \\
6 \\
6 \\
6 \\
6 \\
6 \\
6 \\
6 \\
6 \\
6 \\
6\end{array}$ & $\begin{array}{l}941.4 \\
945.8 \\
901.5 \\
944.0 \\
901.4 \\
942.3 \\
943.4 \\
944.1 \\
943.4 \\
942.6 \\
942.8 \\
943.2 \\
943.2 \\
943.0\end{array}$ & $\begin{array}{r}2.1 \\
8.2 \\
0.4 \\
43.8 \\
0.0 \\
8.6 \\
6.2 \\
6.8 \\
9.1 \\
8.1 \\
6.1 \\
10.8 \\
13.3 \\
16.5\end{array}$ & $\begin{array}{r}997.9 \\
972.1 \\
922.5 \\
959.9 \\
911.0 \\
1006.0 \\
1009.0 \\
979.6 \\
995.6 \\
990.7 \\
997.7 \\
992.3 \\
999.1 \\
999.8\end{array}$ & $\begin{array}{l}943.27 \\
\pm 1.03\end{array}$ & $6.00 \pm .17$ \\
\hline $\begin{array}{l}7 \\
7 \\
7 \\
7 \\
7 \\
7\end{array}$ & $\begin{array}{l}938.8 \\
939.1 \\
938.8 \\
939.5 \\
939.6 \\
939.0\end{array}$ & $\begin{array}{r}13.8 \\
8.0 \\
10.8 \\
7.7 \\
7.6 \\
9.3\end{array}$ & $\begin{array}{l}981.0 \\
997.9 \\
987.4 \\
998.0 \\
991.7 \\
984.3\end{array}$ & $\begin{array}{c}939.13 \\
* 0.32\end{array}$ & $6.67 * .05$ \\
\hline $\begin{array}{l}8 \\
8 \\
8 \\
8 \\
8\end{array}$ & $\begin{array}{l}932.7 \\
932.6 \\
932.7 \\
931.2 \\
932.6\end{array}$ & $\begin{array}{r}11.1 \\
10.0 \\
11.9 \\
8.9 \\
6.4\end{array}$ & $\begin{array}{r}982.0 \\
985.2 \\
986.2 \\
996.1 \\
1002.0\end{array}$ & $\begin{array}{l}932.6 \\
* 0.58\end{array}$ & $7.76+.09$ \\
\hline $\begin{array}{l}9 \\
9 \\
9 \\
9 \\
9 \\
9\end{array}$ & $\begin{array}{l}925.3 \\
924.6 \\
924.9 \\
924.6 \\
924.7 \\
924.1\end{array}$ & $\begin{array}{r}35.0 \\
42.0 \\
38.8 \\
20.6 \\
6.6 \\
12.7\end{array}$ & $\begin{array}{r}1003.2 \\
990.6 \\
985.3 \\
996.2 \\
992.9 \\
997.7\end{array}$ & $\begin{array}{l}924.70 \\
\pm 0.37\end{array}$ & $9.00 \div .06$ \\
\hline
\end{tabular}

*Based upon a linear fit pegged at $6 \%$ and $9 \%$. 


\section{RECENT TEST RESULTS}

A second test of the instrumentation was performed at the Kaiser Mead Plant on August 18, 1988. A series of 18 measurements were made over a $t$ ime interval of 90 minutes. Thus, a measurement cycle takes on the average of 5 minutes. During this period one thermocouple developed a short and was replaced and one dip cup fell off as a result of the nichrome wire support melting during its fourth insertion into the bath. The replacement of this dip cup was also included in the 90-minute activity. The nichrome wire on the first and the last (third) dip cups did not indicate any weakness or melting even though one was dipped 9 times and the other was dipped 6 times.

The data taken during this second test is shown in Table 3. A total of 8 readings taken in Pot 2 yielded a mean value of $942.3^{\circ} \mathrm{C}$ for the transition temperature (the temperature at which thermal arrest occurs). The standard deviation for these readings was $3.9^{\circ} \mathrm{C}$, and the estimated standard error of the mean is calculated as $1.4^{\circ} \mathrm{C}$. Pot 3 had a mean transition temperature of $964.3^{\circ} \mathrm{C}$ with a standard deviation on individual readings of $6.1^{\circ} \mathrm{C}$. The estimated standard error of the mean is $2.0^{\circ} \mathrm{C}$. The manner in which these statistical values are calculated is discussed in Appendix A.

The equation used to calculate the percent alumina in the bath is taken from lee et al. (1984). This equation is

$$
\begin{aligned}
\mathrm{T}(\mathrm{Liquidus})(\mathrm{deg} . \mathrm{C}) & =1009.4+4.059\left(\mathrm{CaF}_{2}\right)-1.167\left(\mathrm{CaF}_{2}\right)^{2} \\
& +0.968\left(\mathrm{CaF}_{2}\right)\left(\mathrm{AlF}_{3}\right)-0.105\left(\mathrm{CaF}_{2}\right)\left(\mathrm{AlF}_{3}\right)^{2} \\
& +0.073\left(\mathrm{CaF}_{2}\right)^{2}\left(\mathrm{AlF}_{3}\right)+0.002\left(\mathrm{CaF}_{2}\right)^{2}\left(\mathrm{AlF}_{3}\right)^{2} \\
& =4.165\left(\mathrm{AlF}_{3}\right)-0.054\left(\mathrm{AlF}_{3}\right)^{2}-5.33\left(\mathrm{Al}_{2} \mathrm{O}_{3}\right) \\
& =1009.4+\mathrm{K}-5.33\left(\mathrm{Al}_{2} \mathrm{O}_{3}\right) .
\end{aligned}
$$

The equation is valid only if the $\mathrm{CaF}_{2}$ content 1 ies between $3.8 \%$ and $11 \%$ and the excess $\mathrm{AlF}_{3}$ content lies between $5 \%$ and $20 \%$. The factor ' $\mathrm{K}$ ' is defined by the equation. It represents all terms other than the first and last.

The transition temperature that is observed using the dip cup is related to the liquidus temperature but may not be identical to it. It is possibie that the liquid supercools under the conditions that the measurement is made. 
It was observed that the transition temperature, $T t$, was given correctly by this equation if the constant 1009.4 is lowered to 1001 . Thus, in calculating the alumina content, the following equation was used:

$$
A 1_{203}=(1001+K-T t) / 5.33 .
$$

The results obtained using this equation are given in Table 3 and are in good agreement with the alumina content independently determined by chemical analysis also shown in Table 3.

TABLE 3. Sunnary of Measurement Results

ROOM 4/POT 2

Bath Ratio

$\mathrm{CaF}_{2}$

Alumina Content by:

Chemical Analysis $3.34 \%$

Dip Cup Instrument $3.29 \%$

Set of Measured

Transition Temperatures

$937.8^{\circ} \mathrm{C}$

937.7

943.0

939.8

945.9

941.2

946.7

946.8

Mean Value

Standard Deviation

Standard Error
1.126

$4.8 \%$

$\mathrm{Tm}=942.3^{\circ} \mathrm{C}$

$\mathrm{s}=3.9^{\circ} \mathrm{C}$

$v=1.4^{\circ} \mathrm{C}$

ROOM 4/POT 3

Bath Ratio

$\mathrm{CaF}_{2}$

Alumina Content by: Chemical Analysis $3.60 \%$ Dip Cup Instrument $3.67 \%$

Set of Measured Iransition Temperatures
$956.5^{\circ} \mathrm{C}$
962.5
958.9
958.4 **
971.0
971.0
962.0
973.0
965.0

$\begin{array}{ll}\text { Mean Value } & \mathrm{Tm}=965.5^{\circ} \mathrm{C} \\ \text { Standard Deviation } & \mathrm{s}=6.1^{\circ} \mathrm{C} \\ \text { Standard Error } & v=2.0^{\circ} \mathrm{C}\end{array}$

* Lost Dip Cup

** Data taken after new Dip Cup installed. 


\section{DISCUSSION OF ACCURACY}

In the laboratory measurements taken at high concentrations of alumina with no $\mathrm{CaF}_{2}$, the standard deviation in the determination of alumina content was $0.17 \%$ or less. The measurements from this second field test at a production plant had much larger spread. A standard deviation of $3.9^{\circ} \mathrm{C}$ (Pot 2) for the transition temperature is equivalent to a standard deviation of $0.73 \%$ in the determination of alumina content. Any individual measurement of alumina content might vary from $2.56 \%$ to $4.02 \%$ where the Mean Value is $3.29 \%$. Similarly, on Pot 3, with a standard deviation of $6.1^{\circ} \mathrm{C}$ in transition temperature, the corresponding standard deviation in the determination of alumina content would be $1.14 \%$ so that values of alumina content would vary from $2.54 \%$ to $4.82 \%$ on a mean value of $3.68 \%$.

In order to obtain greater accuracy, it will be necessary to take a set of $N$ measurements with $N$ being about 9 . In this way, a mean value is established which, for the transition temperature in the tests reported here, had a standard error of $1.4^{\circ} \mathrm{C}$ for Pot 2 and $2^{\circ} \mathrm{C}$ for Pot 3 . This is equivalent to a standard error of $0.26 \%$ in alumina content for Pot 2 and $0.38 \%$ for Pot 3.

Further use of the instrument could point the way to improvements which would result in measurements of greater accuracy. It would seem that the repeatability observed in tests in the laboratory could be achieved in a production plant. 



\section{REVIEW OF PREYIOUS MEASUREMENTS}

A set of measurements were taken at the Kaiser Mead plant on September 22. 1987. The results were reported to Rick James in a letter dated October 14, 1987, and in a memo dated October 7, 1987, to M. J. McMonigle of the U. S. Department of Energy. At the time there was no provision in the computational program to account for the $\mathrm{CaF}_{2}$ content. Corrections to the reported results can now be made. The corrected values of alumina content are given in Table 4 . Both Pots were in Room 48.

Table 4. Sumbary September 22, 1987, Measurements

\begin{tabular}{|c|c|c|c|c|}
\hline Pot & $\begin{array}{l}\text { Bath } \\
\text { Ratio } \\
\end{array}$ & $\mathrm{CaF}_{2}$ & $\begin{array}{l}\text { Transition } \\
\text { Temperature }\end{array}$ & $\begin{array}{c}\text { Calculated } \\
\text { Alumina Content }\end{array}$ \\
\hline$\frac{1}{2}$ & $\begin{array}{l}1.13 \\
1.18\end{array}$ & $\begin{array}{l}5.3 \% \\
5.8 \%\end{array}$ & $\begin{array}{l}935.4^{\circ} \mathrm{C} \\
956.3^{\circ} \mathrm{C}\end{array}$ & $\begin{array}{l}4.94 \% \\
3.60 \%\end{array}$ \\
\hline
\end{tabular}





\section{REFERENCES}

Lee, S. S., K. S. Lei, P. Xu, and J. J. Brown. 1984. "Determination of Melting Temperatures and A1203 Solubilities for Hall Cell Electrolyte Compositions." In Light Metals 1984, Proceedings of the Technical Sessions Sponsored by the TMS Light Metals Committee at the 113th Annual Meeting, Ed. J. P. McGeer, pg. 841. The Metallurgical Society of AIME, Warrendale, Pennsylvania. 
. 
APPENDIX

ESTIMATES OF ACCURACY AND ERROR 
APPENDIX

\section{ESTIMATES OF ACCURACY AND ERROR}

When a quantity $Q$ is measured repeatedly, the values measured are generally found to differ somewhat from measurement. Let $Q i$ be the values determined in measurement number $i$. The Mean Value of a set of $\mathbb{N}$ measurements is the average value and is calculated using the equation

$$
Q m=\left(\sum_{i=1}^{N} Q \mathbf{i}\right) / N
$$

The limit of Qm as $N$ tends toward infinity is known as the Parametric Mean, $M$, of the quantity. Qm may therefore be considered as an estimate of $M$ based upon $\mathbf{N}$ measurements.

Standard Deviation is a measure of the accuracy of a single measurement in the determination of the Parametric Mean, $M$. However, since the true value of $M$ is never known (we have only the estimates Qm), Standard Deviation, $s$, is calculated using the equation

$$
s=\operatorname{SQR}\left(\sum_{i=1}^{N}(Q m-Q i)^{2 /(N-1)}\right)
$$

An estimate of the deviation of the value Qm from the Parametric Mean, $M$, is known as the Standard Error and is given by

$$
v=s /\left(N^{0.5}\right)=s /(\operatorname{SQR}(N))
$$

In the case of the recent measurements at Kaiser Mead, the following results are obtained:

- Room 4 Pot 2

A set of 8 measurements of the transition temperature (assumed to be related to the liquidus Temperature) gave a mean value, $\mathrm{Tm}$, of $942.3^{\circ} \mathrm{C}$. 
The standard deviation, calculated as indicated above, gave a value of $s=3.9^{\circ} \mathrm{C}$. The standard error would therefore be

$$
v=3.9 / \mathrm{SQR}(8)=1.4^{\circ} \mathrm{C} .
$$

- Room 4 Pot 3

A set of 9 measurements of the transition temperature gave a mean value, $T m_{1}$ of $964.3^{\circ} \mathrm{C}$ with $s=6.1^{\circ} \mathrm{C}$ and $v=2^{\circ} \mathrm{C}$. 


\section{DISTRIBUTION}

No. of

Copies

OFFSITE

10 DOE/Office of Scientific and Technical Information

R. James

Kaiser Aluminum and Chemical Corporation

East 2111 Hawthorne

Mead WA 99021

M. J. Sawatzky

Kaiser Aluminum and Chemical Corporation

East 2111 Hawthorne

Mead WA 99021

M. J. McMonigle

U.S. Department of Energy

Office of Industrial Programs

Forrestal Building

Mail Stop CE-12

1000 Independence Avenue

Washington DC 20585

\section{ONSITE}

DOE Richland Operations Office

J. J. Sutey

13 Pacific Northwest Laboratory

B. B. Brenden (3)

M. Clement

P. E. Hart

O. H. Koski

K. H. Pool

Technical Report Files (5)

Publishing Coordination 


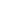

